- Shows how clinical audit can improve standards in cross infection control.

- Sufficient details are given to allow other clinicians to replicate the audit in other dental

- American Dental Association and European Union water quality recommendations are listed as acceptable standards to adopt.

\title{
An audit improves the quality of water within the dental unit water lines of three separate facilities of a United Kingdom NHS Trust
}

\author{
R. A. C. Chate $^{1}$
}

Objective To improve the quality of water emanating from dental unit waterlines (DUWLS). Design A prospective clinical audit. Setting Three geographically separate district dental facilities of a United Kingdom NHS Trust, involving two community clinics and one hospital orthodontic department, which were evaluated between 2002 and 2004. Methods Samples of water discharged from the DUWLs were collected prior to the start and midway through a morning session. These were tested microbiologically at a United Kingdom Accreditation Service testing laboratory within six hours of sampling. Interventions One of the clinics followed the contemporaneous BDA advice of flushing water through its DUWLs while the other two clinics used separate intermittent disinfection purging regimes instead. One of them used a two stage protocol of Ethylene Diamine Tetra-Acetic acid followed by hydrogen peroxide, while the other used Bio 2000 as a single agent, which was subsequently superseded by the continuous use of super-oxidised water (Sterilox). Main outcome measure To assess whether the samples either met the American Dental Association's guideline on the quality of DUWL water, or the more stringent European Union standards for potable (drinking) water. Results The two units which used a disinfection regime both complied with the ADA guideline and the EU potable water standard. However, the unit which only flushed through its DUWLs without using a disinfectant failed to comply with either of them. After all three dental facilities subsequently standardised their DUWL disinfection regimes by using Bio 2000, the colony counts from all of the water samples thereafter remained well below the EU recommended level. The unit which progressed to using Sterilox as a continuous disinfectant achieved and maintained zero readings from its water samples. Conclusions Clinical audit can result in the improvement of the quality of water that is discharged through DUWLs, thereby minimising both the risk of cross infection to vulnerable patients, as well as to dental staff chronically exposed to contaminated aerosols.

\section{INTRODUCTION}

Biofilms which form within dental unit water lines (DUWLs) do so within a few weeks of each unit's installation and connection to a water supply. ${ }^{1}$ They consist mainly of bacteria in a complex communal architecture enveloped in a

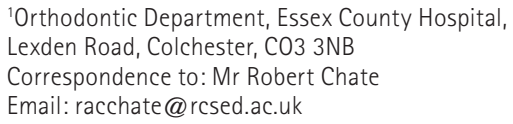

${ }^{\circ}$ British Dental Journal 2006; 201: 565-569 self-generated glycocalyx polysaccharide slime, which protects the microbes from desiccation, chemical insult, predation and immunological attack. ${ }^{2}$

Most of the microorganisms are aerobic, gram negative, non-coliform water bacteria that have limited pathogenic potential in immuno-competent people. ${ }^{2}$

DUWL biofilms are typically colonised by Pseudomonas aeruginosa, Legionella pneumophila, non-tuberculous mycobacteria (NTM), and Eschericia, as well as by oral flora, such as Bacteroides, streptococci, Actinomyces, lactobacilli, staphylococci, Veillonella, and Candida.,4
Despite the routine use of anti-retraction valves, salivary blood borne hepatitis B and HIV have been shown experimentally to be sucked back into handpieces and have been recovered distally in dental waterlines. ${ }^{1}$ Concern has been expressed that theoretically this could also occur with prions. ${ }^{5}$

While at present there are no legal standards which apply to the quality of water emanating from DUWLs, a decade ago the American Dental Association (ADA) recommended that by the year 2000, there should be no more than 200 colony forming units per $\mathrm{ml}(\mathrm{cfu} / \mathrm{ml})$ in 
water samples after 72 hours of culturing at $22^{\circ} \mathrm{C} .{ }^{6}$ Separately, the European Union (EU) has set a standard for potable (drinking) water, namely the absence of E. coli or any other faecal coliforms, and with an aerobic colony count of less than $100 \mathrm{cfu} / \mathrm{ml}$, after 72 hours of culturing at $22^{\circ} \mathrm{C}$, or of $20 \mathrm{cfu} / \mathrm{ml}$, after 24 hours of culturing at $37^{\circ} \mathrm{C} .^{7}$

Since then, a couple of studies have surveyed the compliance with these targets amongst general dental practices, both in the UK and in Europe. Out of 55 English dental practices, 95\% of their DUWL levels of contamination were found to have exceeded the EU standard for potable water, with $83 \%$ failing to meet the ADA DUWL recommendation, ${ }^{8}$ while amongst 237 dental practices across seven European countries, 51\% exceeded the ADA guideline. ${ }^{9}$

In absolute terms, the mean levels of contamination reported for European dental practices have ranged from 32$320 \mathrm{cfu} / \mathrm{ml},{ }^{9}$ while for those in Great Britain and Ireland, the levels have been much higher at around 2,500 $\mathrm{cfu} / \mathrm{ml}, 8,10$ and $66,000 \mathrm{cfu} / \mathrm{ml},{ }^{11,12}$ with similar readings being obtained from hospital dental units as well. ${ }^{11}$

Despite the general prevalence of such high recordings, there still remains no scientific evidence that DUWL biofilms represent a public health risk. It has been postulated that this could either be due to the true absence of disease transmission, or because of the difficulty of establishing any epidemiological links between infections with extended incubation times and antecedent dental procedures. ${ }^{13}$

Nevertheless, immunocompromised and immunosuppressed patients are more susceptible to infection from waterborne opportunistic pathogens. ${ }^{1,14}$ For example, two such patients have been previously infected orally with Pseudomonas aeruginosa from a hospital's dental unit water supplies, ${ }^{15}$ and concern has been expressed that aerosolisation of this microorganism's related species of Burkholderia cepacia could also pose a threat to patients with cystic fibrosis, as these microbes are known to be important respiratory pathogens in this disease. ${ }^{4}$

Further, with NTM being recovered from 5\% of 55 English general dental practice DUWLs, ${ }^{8}$ and with the mean levels of contamination of 365 $\mathrm{cfu} / \mathrm{ml}$ amongst 21 German dental office DUWLs being 400 times that of the local water supply, ${ }^{16}$ it is not surprising that others have implicated a dental origin as the source of some patients' NTM infections, where one case involved the NTM infection of a prosthetic heart valve after a patient had received dental treatment, ${ }^{17}$ and another two patients developed NTM cervical lymphadenitis after undergoing dental extractions. ${ }^{18}$

Legionella pneumophila, the organism responsible for Legionnaires' disease, ${ }^{2}$ has also been recovered from the DUWLs of $1 \%$ of European general dental practices, ${ }^{9}$ up to $2 \%$ of British dental practices, ${ }^{8,19}$ and between 2-8\% of American dental offices. ${ }^{20,21}$ Higher recovery rates have been associated with water samples taken from dental hospitals and other large institutions, specifically $21.8 \%$ from Italian private and public institutions, ${ }^{22}$ and 25\% from a London dental hospital. ${ }^{23}$ This is because storage of water in large tanks acts as a reservoir for repeated seeding of the plumbing system, and complex plumbing systems found in large institutions are more prone to colonisation with legionellae, where the sludge in the tanks and the DUWL biofilms both provide favourable growth conditions. ${ }^{19}$

Although L. pneumophila is not the dominant component in dental unit water, heavy exposure to species of Legionella should be investigated as a potential health risk for both dental personnel and their immunocompromised patients. $^{20}$

Indeed, 20\% of American ${ }^{24}$ and 34\% of Austrian dental personnel have been found to have significantly higher serological levels of antibodies against $L$. pneumophila as compared to controls, ${ }^{25}$ although this has not been found to be the case amongst a sample of 266 UK dentists. ${ }^{19}$

Nevertheless, the death of a Californian dentist with legionellosis seems as if it can be almost attributable to his exposure to the high levels of Legionella spp. found in his dental operatory, with it being likely that the contaminated aerosols from his dental units were the source of his fatal infection. ${ }^{20}$

Another potential risk to clinical staff from contaminated aerosols relates to the development of asthma. It is known that endotoxin exposure exacerbates asthma, and that Gram-negative bacteria which contain cell wall endotoxins predominate the flora in DUWLs. ${ }^{2,26}$ Nevertheless, while one study of a group of 266 UK dentists has not found a significant association between the two in general, amongst a subset of 33 dentists who reported developing asthma since they started their dental training, exposure to passive smoking and separately, exposure to aerobic colony counts at $37^{\circ} \mathrm{C}$ of greater than $200 \mathrm{cfu} / \mathrm{ml}$ were both found to be significant. ${ }^{12}$

The aim of this study was therefore to survey the quality of water emanating from the DUWLs which supplied irrigation for the dental hand-pieces and triple spray syringes across three separate district dental facilities of an NHS Trust, and to undertake an audit to establish an acceptable standard.

\section{METHODS}

\section{Setting}

Three geographically separate district dental facilities of a United Kingdom NHS Trust, involving two community clinics and one hospital orthodontic department, took part in this prospective clinical audit between 2002 and 2004. One of the community dental clinics was based in the centre of Colchester, and predominantly treated patients with special needs, including those with complex medical histories, and as such, with increased vulnerability to cross infection. The other community dental clinic was based at a peripheral cottage hospital in Halstead, where both special needs and healthy children were treated, the latter mainly for orthodontic therapy. The hospital orthodontic department was situated in Essex County Hospital, where patients with severe malocclusions requiring complex multidisciplinary management were treated, alongside a smaller number of routine orthodontic cases associated with medical compromise.

\section{Interventions}

One of the clinics, Unit A, followed the contemporaneous BDA advice of flushing water through the DUWLs for two minutes at the beginning of each day, and for 20-30 seconds after the treatment of each patient. Its dental units were comprised of Dentaleze carts supplied by Bondent and connected to Belmont chairs, having been installed in 1992, 10 years before the audit, and 
they were supplied with water directly from the mains. The other two clinics used separate weekly intermittent disinfection purging regimes instead. One of them, Unit B, used a two stage protocol involving the initial use of ethylene diamine tetra-acetic acid (EDTA) sodium salt in distilled water at $5 \mathrm{~g}$ per litre as a cleaning agent, followed by $0.3 \%$ hydrogen peroxide $\left(\mathrm{H}_{2} \mathrm{O}_{2}\right)$ as the disinfectant (Castellini UK Ltd, Nottingham, NG7 2NN, UK). Its dental units were also Dentaleze carts supplied by Bondent and connected to Belmont chairs, having been installed in 1994, eight years before the audit, and the routine weekly disinfection of the DUWLs had begun 12 months before the first water sample was taken. In between each disinfection event, sterile water from an independent water bottle had been used for the irrigation of the dental handpieces and the triple spray syringes. By the time of the second water sample test, this unit had changed its DUWL disinfectant to Bio 2000 (Micrylium, Temple, Arizona, 85281, USA), a single agent whose active ingredients were ethanol and chlorhexidine, and which by then had been in use for eight months.

The other clinic, Unit C, had initially used the EDTA and $\mathrm{H}_{2} \mathrm{O}_{2}$ regime the longest, for two and a quarter years before switching to the use of Bio 2000, four months before the start of the audit. Towards the end of the audit, this in turn was subsequently superseded by Sterilox, a super-oxidised water (Optident, Ilkley, LS29 8PB, UK), a dilute disinfectant designed for continuous use. In between each disinfection cycle, sterile water from an independent water reservoir had also been used to supply the dental instrumentation. While this unit's Castellini Area 4C Thesi dental chairs had been installed in 1991, the dental unit waterline tubings had been replaced two years before the audit, six months after the onset of the routine DUWL disinfection process in 1999.

\section{Water sampling}

To test the water on each occasion, 250 $\mathrm{ml}$ samples were discharged from the DUWLs in the community and orthodontic clinics, just prior to the start and midway through a mid-week morning session. These were collected aseptically in sterile bottles containing $0.1 \mathrm{~g}$ of sodium thiosulphate, in order to neutralise either any residual chlorine or disinfectant left in the water. ${ }^{12,27,28}$

The samples were stored in a refrigerator until transfer to the laboratory using a cool box could be made, in less than six hours as recommended.

The processing of the samples was undertaken in a United Kingdom Accreditation Service testing laboratory, and they were analysed not only for aerobic colony counts at $22^{\circ} \mathrm{C}$ after 72 hours, and $37^{\circ} \mathrm{C}$ after 24 hours, using a standard pour plate method as outlined in detail elsewhere, ${ }^{10,28,29}$ but also for the possible presence of coliforms using a recognised technique (Enumeration of coliforms and Escherichia coli by membrane filtration. Health Protection Agency 2004. National Standard Method. W2, Issue 3. www.hpa-standardmethods.org.uk/ pdf_sops.asp).

\section{Audit standards}

The standards that were set for the audit were that the samples should at least meet the American Dental Association's (ADA) guideline on the quality of DUWL water, but preferably that they should reach the European Union (EU) standards for potable (drinking) water.

\section{RESULTS}

Neither E. coli nor any coliforms were recovered from the water samples taken from any of the three units, on any occasion.

Table 1 illustrates that while Unit A met both the ADA and EU standards for water quality when the initial two samples were cultured at $37^{\circ} \mathrm{C}$, they both failed when they were cultured at $22^{\circ} \mathrm{C}$, with more than $3,000 \mathrm{cfu} / \mathrm{ml}$ being recorded.

In contrast, the water samples from
Units B and C were both well below either the American or European guideline levels.

Subsequent to these results, Unit A undertook the installation of independent water bottle reservoirs to each of its department's chairs, in order to facilitate the inauguration of a weekly DUWL disinfection regime. Unit B also discontinued the use of the dual EDTA and $\mathrm{H}_{2} \mathrm{O}_{2}$ disinfection protocol, in favour of the single agent Bio 2000 disinfectant regime that had been successfully used in Unit C.

Table 2 illustrates the water quality results of the samples taken 10 months later at the second audit. By this time, all three units had become standardised in their weekly use of Bio 2000, with Unit A having used it for seven weeks before the sample collections, and with Units B and $\mathrm{C}$ for nine and 14 months respectively. In between the weekly purges, all of the units had used sterile water as the irrigant for the dental handpieces and the triple spray syringes.

The data show that this protocol had successfully maintained the desired DUWL water quality for both Units B and C, but not for Unit A - that is apart from one of the samples which had been collected prior to the start of the morning session, and which had been cultured at $22^{\circ} \mathrm{C}$ for 72 hours. Here the reading of $180 \mathrm{cfu} / \mathrm{ml}$ was just below the ADA guideline, but well above the EU potable water standard.

After receiving appropriate microbiological advice, in an effort to establish an acceptable water quality standard for Unit A, its DUWLs were then subjected to a month of continuous use of the Bio 2000 , in order to be certain that the biofilms had been maximally disinfected.

\begin{tabular}{|c|c|c|c|c|c|c|}
\hline Unit & \multicolumn{2}{|l|}{ A } & \multicolumn{2}{|l|}{ B } & \multicolumn{2}{|l|}{ C } \\
\hline DUWL disinfectant & \multicolumn{2}{|l|}{ None } & \multicolumn{2}{|c|}{$\mathrm{EDTA}+\mathrm{H}_{2} \mathrm{O}_{2}$} & \multicolumn{2}{|c|}{ Bio 2000} \\
\hline Mode of use & \multicolumn{2}{|l|}{ None } & \multicolumn{2}{|c|}{$\begin{array}{l}\text { Intermittent } \\
\text { weekly purges }\end{array}$} & \multicolumn{2}{|c|}{$\begin{array}{l}\text { Intermittent } \\
\text { weekly purges }\end{array}$} \\
\hline Date of test & \multicolumn{2}{|c|}{09.04 .2002} & \multicolumn{2}{|c|}{09.04 .2002} & \multicolumn{2}{|c|}{09.04 .2002} \\
\hline Sample collection time & $08: 55$ & $10: 25$ & 09:00 & $11: 30$ & $08: 55$ & $10: 30$ \\
\hline Total coliforms/100 ml & 0 & 0 & 0 & 0 & 0 & 0 \\
\hline Escherichia coli/100 ml & 0 & 0 & 0 & 0 & 0 & 0 \\
\hline $\begin{array}{l}\text { Aerobic colony count cfu/ml }\left(37^{\circ} \mathrm{C}\right. \\
\text { after } 24 \mathrm{hrs})\end{array}$ & 1 & 0 & 0 & 1 & 6 & 0 \\
\hline $\begin{array}{l}\text { Aerobic colony count cfu } / \mathrm{ml}\left(22^{\circ} \mathrm{C}\right. \\
\text { after } 72 \mathrm{hrs})\end{array}$ & $\begin{array}{l}>3 x \\
10^{3}\end{array}$ & $\begin{array}{l}>3 x \\
10^{3}\end{array}$ & 3 & 0 & 0 & 0 \\
\hline
\end{tabular}




\begin{tabular}{|c|c|c|c|c|c|c|}
\hline Unit & \multicolumn{2}{|l|}{$A$} & \multicolumn{2}{|l|}{$B$} & \multicolumn{2}{|l|}{$\mathrm{C}$} \\
\hline DUWL disinfectant & \multicolumn{2}{|c|}{ Bio 2000} & \multicolumn{2}{|c|}{ Bio 2000} & \multicolumn{2}{|c|}{ Bio 2000} \\
\hline Mode of use & \multicolumn{2}{|c|}{$\begin{array}{l}\text { Intermittent weekly } \\
\text { purges }\end{array}$} & \multicolumn{2}{|c|}{$\begin{array}{l}\text { Intermittent weekly } \\
\text { purges }\end{array}$} & \multicolumn{2}{|c|}{$\begin{array}{l}\text { Intermittent weekly } \\
\text { purges }\end{array}$} \\
\hline Date of test & \multicolumn{2}{|c|}{21.02 .2003} & \multicolumn{2}{|c|}{11.02 .2003} & \multicolumn{2}{|c|}{11.02 .2003} \\
\hline Sample collection time & $08: 25$ & $10: 25$ & $08: 45$ & $10: 45$ & $08: 55$ & $10: 30$ \\
\hline Total coliforms/100 ml & 0 & 0 & 0 & 0 & 0 & 0 \\
\hline Escherichia coli/100 ml & 0 & 0 & 0 & 0 & 0 & 0 \\
\hline $\begin{array}{l}\text { Aerobic colony count } \\
\mathrm{cfu} / \mathrm{ml}\left(37^{\circ} \mathrm{C} \text { after }\right. \\
24 \mathrm{hrs})\end{array}$ & 170 & $>3 \times 10^{3}$ & 1 & 0 & 0 & 2 \\
\hline $\begin{array}{l}\text { Aerobic colony count } \\
\text { cfu/ml }\left(22^{\circ} \mathrm{C} \text { after }\right. \\
72 \mathrm{hrs})\end{array}$ & 180 & $>3 \times 10^{3}$ & 3 & 0 & 0 & 3 \\
\hline
\end{tabular}

Table 3 shows that when Unit A's water samples had been retested three days later, zero readings had been achieved. After this, Unit A reverted to the weekly disinfection regime, and when its water samples were checked again two months later, it was clear that at that stage its DUWL quality had reached comparability with the earlier readings of the other two units, being well within the agreed audit standards.

Coincidentally, nine months later Unit C switched to using Sterilox, and after four months of usage this unit's water was sampled again in isolation. As with Unit A's continuous use of the other disinfectant Bio 2000, zero readings had also been obtained.

\section{DISCUSSION}

Each unit had two samples of water collected on every test occasion, in order to measure what effect both overnight DUWL stagnation and flushing through of the lines during normal clinical use had had on the levels of microbial contamination. Table 1 shows that Unit A, which had relied on the regime of simply discharging water through its lines, as recommended contemporaneously by the $\mathrm{BDA},{ }^{30}$ the $\mathrm{ADA},{ }^{3}$ and the Centers for Disease Control, ${ }^{31}$ had clearly failed to reach an acceptable DUWL quality level.

Indeed, others have shown that flushing fails to reduce DUWL microbial contamination by anything more than $9 \% .^{32}$ Instead, paradoxically bacterial counts can increase, as and when portions of the biofilm detach from the lining of the tubes and slough off into the water. ${ }^{2,33,34}$

Table 2 demonstrates this phenomenon when the mid morning session water samples for Unit A are considered. Why this unit's DUWL aerobic colony counts remained unacceptably high after following the manufacturer's instructions for passing the Bio 2000 disinfectant through its lines remains unclear. It might have been because it was the oldest unit in the audit, with only seven weeks of disinfection prior to the

\begin{tabular}{|c|c|c|c|c|c|c|}
\hline Unit & \multicolumn{2}{|l|}{ A } & \multicolumn{2}{|l|}{ A } & \multicolumn{2}{|l|}{ C } \\
\hline DUWL disinfectant & \multicolumn{2}{|c|}{ Bio 2000} & \multicolumn{2}{|c|}{ Bio 2000} & \multicolumn{2}{|c|}{ Sterilox } \\
\hline Mode of use & \multicolumn{2}{|c|}{ Continuous use } & \multicolumn{2}{|c|}{$\begin{array}{l}\text { Intermittent } \\
\text { weekly purges }\end{array}$} & \multicolumn{2}{|c|}{$\begin{array}{l}\text { Continuous } \\
\text { use }\end{array}$} \\
\hline Date of test & \multicolumn{2}{|c|}{17.04 .2003} & \multicolumn{2}{|c|}{ 19.06.2003 } & \multicolumn{2}{|c|}{ 29.07.2004 } \\
\hline Sample collection time & $08: 30$ & $10: 30$ & $08: 20$ & $10: 30$ & 09:00 & $11: 00$ \\
\hline Total coliforms/100 ml & 0 & 0 & 0 & 0 & 0 & 0 \\
\hline Escherichia coli/100 ml & 0 & 0 & 0 & 0 & 0 & 0 \\
\hline $\begin{array}{l}\text { Aerobic colony count cfu/ml } \\
\left(37^{\circ} \mathrm{C} \text { after } 24 \mathrm{hrs}\right)\end{array}$ & 0 & 0 & 1 & 8 & 0 & 0 \\
\hline $\begin{array}{l}\text { Aerobic colony count cfu/ml } \\
\left(22^{\circ} \mathrm{C} \text { after } 72 \mathrm{hrs}\right)\end{array}$ & 0 & 0 & 2 & 0 & 0 & 0 \\
\hline
\end{tabular}

second test, however, a previous study has found no evidence to suggest that the age of a unit has any influence on the microbiological quality of its water. ${ }^{10}$ In contrast, previous research has shown that levels of contamination appear to be related to different models of dental units, even in those present in the same department with the same water supply and virtually identical clinical usage. ${ }^{23}$

Table 3 shows that the continuous use of Bio 2000 successfully rendered Unit A's DUWL water as drinkable, but anecdotally, not without a great number of patients complaining that the water tasted bitter. Not so for Unit C, which ultimately employed Sterilox as its DUWL disinfectant. Apart from the initial shock treatment of a concentrate of this solution through the water lines at the start of its use, ${ }^{2}$ this product allows a $5 \%(\mathrm{v} / \mathrm{v})$ dilution of Sterilox to sterile water to be used continuously thereafter, without the subsequent need to periodically decommission a dental chair for a couple of hours while an intermittent disinfectant is purged through its DUWLs by a member of staff instead.

of all the main disinfectants which can be used inside DUWLs, experimentally only Alpron, Sterilox, sodium hypochlorite, and Bio 2000 have been shown to completely eliminate the total viable counts of bacteria in the water. In descending order, all of them have also been shown to reduce the biofilm coverage within DUWL tubes by a variable amount, namely by 100\%, 99\%, 94\%, and 53\% respectively. ${ }^{32}$

For Alpron and Sterilox in particular, these effical findings have also been borne out by a couple of clinical studies. ${ }^{27,29}$

As such, with at least two effective DUWL disinfection systems now available, it would be difficult to justify the continued use of untreated dental unit water containing bacterial counts greater than those recommended by the EU. ${ }^{27}$

Indeed, not withstanding the Health and Safety legal requirement for general dental practice employers to manage the risk of Legionnaires' disease from any source of their premises' water, ${ }^{1,35}$ using heavily contaminated water from a dental unit could ultimately expose a clinician to a variety of legal proceedings. ${ }^{36}$

Some might argue that this is only of relevance for those involved in treating medically compromised patients within 
specialist centres. However, despite the fact that the GDC has recently approved the establishment of special care dentistry as a speciality, ${ }^{37}$ there is no doubt that as the proportions of the UK population affected by either cancer or profound disability continue to increase by about $1 \%$ each year, the dilemma regarding service delivery will most likely only be resolved by the additional involvement of general practice dentists in the provision of care for these patients, ${ }^{38}$ who will otherwise remain vulnerable to any cross infection control deficiencies.

\section{CONCLUSION}

A clinical audit resulted in the standardisation of an acceptable quality of water that was discharged through the DUWLs of all three separate district dental facilities of an NHS Hospital Trust, thereby minimising the risk of cross infection to the varying number of vulnerable patients that were being treated, as well as the threat to dental staff from chronic exposure to contaminated aerosols.

Thanks to Joanne Thompson and Andy Clayton for participating in this audit, to Dr Tony Elston, Consultant Microbiologist for his advice on the various DUWL disinfection regimes, and to Martin Lodge, Chief Biomedical Scientist for the East of England Health Protection Agency, for the laboratory testing and analysis of all of the water samples, and for his helpful comments on these aspects of the report.

1. Pankhurst $C$ L. Risk assessment of dental unit waterline contamination. Prim Dent Care 2003; 10: 5-10.

2. Mills SE. The dental unit waterline controversy: defusing the myths, defining the solutions. J Am Dent Assoc 2000; 131: 1427-1441.

3. ADA Council on scientific affairs. Dental unit waterlines: approaching the year 2000. J Am Dent Assoc 1999; 130: 1653-1664.

4. Pankhurst C L, Philpott-Howard J N. The environmental risk factors associated with medical and dental equipment in the transmission of Burkholderia (Pseudomonas) cepacia in cystic fibrosis patients. J Hosp Infect 1996; 32: 249-255.

5. Porter S R. Prions and dentistry. J R Soc Med 2002 95: 178-181.

6. Anonymous. ADA statement on dental unit waterlines. J Am Dent Assoc 1996; 127: 185-186.

7. Anonymous. Council directive $98 / 83 /$ EC of 3 November 1998 on the quality of water intended for human consumption. Off J Eur Commun 1998 . L330: 32-54.

8. Walker J T, Bradshaw D J, Bennett A M et al. Microbial biofilm formation and contamination of dental-unit water systems in general dental practice. Appl Environ Microbiol 2000; 66: 3363-3367.

9. Walker J T, Bradshaw D J, Finney M et al. Microbiological evaluation of dental unit water systems in general dental practice in Europe. Eur J Oral Sci 2004; 112: 412-418.

10. Smith A J, McHugh S, McCormick L et al. A crosssectional study of water quality from dental unit water lines in dental practices in the West of Scotland. Br Dent J 2002; 193: 645-648.

11. Tuttlebee C M, O'Donnell M J, Keane C T et al. Effective control of dental chair unit waterline biofilm and marked reduction of bacterial contamination of output water using two peroxide-based disinfectants. J Hosp Infect 2002; 52: 192-205.

12. Pankhurst C L, Coulter W, Philpott-Howard J N et al. Evaluation of the potential risk of occupational asthma in dentists exposed to contaminated dental unit waterlines. Prim Dent Care 2005: 12: 53-59.

13. Shearer B G. Biofilm and the dental office. J Am Dent Assoc 1996; 127: 181-189.

14. Pankhurst $C L$, Johnson N W, Woods R G. Microbia contamination of dental unit waterlines: the scientific argument. Int Dent J 1998; 48: 359-368.

15. Martin M V. The significance of the bacterial contamination of dental unit water systems. Br Dent J 1987; 163: 152-154.

16. Schulze-Robbecke R, Feldmann C. Fischeder R et al. Dental units: an environmental study of sources of potentially pathogenic mycobacteria. Tuber Lung Dis 1995; 76: 318-323.

17. Lohr D C, Goeken J A, Doty D B et al. Mycobacterium gordonae infection of a prosthetic aortic valve. J Am Dent Assoc 1978; 239: 1528-1530.

18. Wallace R J, Swenson J M, Silcox V A et al. Spectrum of disease due to rapidly growing mycobacteria. Rev Infect Dis 1983; 5: 657-777.

19. Pankhurst C L Coulter W, Philpott-Howard J N et al. Prevalence of legionella waterline contamination and Legionella pneumophila antibodies in general dental practitioners in London and rural Northern Ireland. Br Dent J 2003; 195: 591-594.

20. Atlas R M, Williams J F, Huntington M K. Legionella contamination of dental unit waters. Appl Environ Microbiol 1995; 61: 1208-1213.

21. Williams H N, Paszko-Kolva C, Shahamat M et al. Molecular techniques reveal high prevalence of Legionella in dental units. J Am Dent Assoc 1996; 127: 1188-1193.
22. Zanetti F, Stampi S, De-Lucha G et al. Water characteristics associated with the occurence of Legionella pneumophila in dental units. Eur J Oral Sci 2000; 108: 22-28.

23. Challacombe S J, Fernandes L L. Detecting Legionella pneumophila in water systems: a comparison of various dental units. J Am Dent Assoc 1995; 126: 603-608.

24. Fotos P G, Westfall H N, Synder I et al. Prevalence of Legionella-specific $\lg \mathrm{G}$ and $\lg M$ antibody in a dental clinic population. J Dent Res 1985; 64: 1382-1385.

25. Reinthaler F F, Mascher F, Stunzner D. Serological examinations for antibodies against Legionella species in dental personnel. J Dent Res 1988; 67: 942-943.

26. Fulford M R, Walker J T, Martin M V et al. Total viable counts, ATP, and endotoxin levels as potential markers of microbial contamination of dental unit water systems. Br Dent J 2004; 196: 157-159.

27. Martin M V, Gallagher M A. An investigation of the efficacy of super-oxidised (Optident/Sterilox) water for the disinfection of dental unit water lines. Br Dent J 2005; 198: 353-354.

28. Anonymous. The microbiology of water. Part 1 - Drinking water. pp 1-127. London: HMSO, 1994.

29. Smith A J, McHugh S, Aitken I, Hood J. Evaluation of the efficacy of Alpron disinfectant for dental unit water lines. Br Dent J 2002; 193: 593-596.

30. Anonymous. Infection control in dentistry. BDA Advice Sheet A12. London: British Dental Association.

31. Anonymous. Recommended infection-control practices for dentistry. MMWR 1993; 42: 1-11.

32. Walker J T, Bradshaw D J, Fulford M R, Marsh P D. Microbiological evaluation of a range of disinfectant products to control mixed-species biofilm contamination in a laboratory model of a dental unit water system. Appl Environ Microbio/ 2003; 69: 3327-3332.

33. Santiago J I, Huntington M K, Johnston A M et al. Microbial contamination of dental unit waterlines: Short- and long-term effects of flushing. Gen Dent 1994: 48: 528-535.

34. Williams H N, Quinby H, Romberg E. Evaluation and use of a low nutrient medium and reduced incubation temperature to study bacterial contamination in the water supply of dental units. Can J Microbiol 1994; 40: 127-131.

35. Anonymous. Legionnaires' disease: A guide for employers. pp 1-9. Sudbury: Health and Safety Executive, 2001.

36. Croser D. Water: navigating the clinical issues. Riskwise UK Dent Protect 2005: 28: 6-7.

37. Fiske J. Special care dentistry. Br Dent J 2006; 200: 61 .

38. Nunn J H. Special care dentistry - a new speciality. In Hancocks S (Ed) Word of mouth dental health and practice 2006. pp 120-124. London: Atalink Ltd, Year book of the British Dental Health Foundation, 2005. 